\title{
Nursing Education in the Wind of Changes: Estonian Experience
}

\author{
Ü. Ernits, M. Talvik and T. Tulva \\ Chair of Nursing, Tallinn Health Care College, Estonia
}

\begin{abstract}
The purpose of the research is to analyse the development of professional nursing and nurses' training in Estonia in the context of social, ethnic-cultural and political changes. The research shows how this knowledge contributes to the future of nursing profession. The analysis of historical documents was conducted between 2015 and 2018. The development of nursing in Western Europe, Scandinavia, Russia and the Baltic States gives the contextual background in which Estonian nursing started and progressed. The data used in the study are based on summarising and analysing relevant studies, which have been conducted in several European countries. There are four distinct periods in the development of Estonian nursing. The main emphasis of the article is on the last period of development (since 1991), when Estonian nursing became a professional field of study and practice. Curricula have changed, internationalisation has taken place, modern learning methods (NANDA-I, simulation, etc.) have been introduced. Migration of nurses has been a problem in recent years. The reform of higher education and internationalisation has also brought about changes.
\end{abstract}

Keywords: Estonian nursing, nursing education, history of nursing, migration of nurses

\section{Introduction}

The aim of the research is to analyse the development of nursing and the training of nurses in Estonia in the context of social change in four periods: before Estonia's independence, during the Republic of Estonia, during the Soviet period and after the restoration of independence. Emphasis is placed on nursing during the reindependence period, further development perspectives in nursing and nurses' training.

The authors of the research analyse how the four historical periods of educating nurses have changed the development and prestige of the profession, and how this knowledge contributes to the present and future of nursing profession. The history of nursing has not been systematically studied in Estonia so far. The research provides Estonian nurses with a documented history of their profession during critical high and low periods of development. Nursing development in Western Europe, Scandinavia, Russia and the Baltic States gives the contextual background in which Estonian nursing started and progressed. Development of nursing has been influenced by social, historical-cultural, political and ethnic factors.

Virginia M. Dunbar, the administrator the American Red Cross Nursing Services, said in 1937th „Nursing history in the world is the reflection of the history of different countries. Every country seems to illustrate the past or the future of some other country. Each country enlarges upon and 


\section{International Conference on Research in Education}

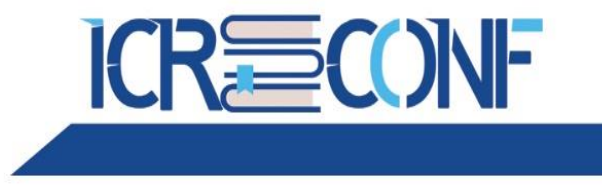

5-7 APRIL, 2019

BARCELONA, SPAIN

acts out some step in the progress of another (Dunbar, 1937). As long as society is changing, and nurses are going to meet and adapt to societies' needs, the education of nurses will also have to change continuously (Kyrkjebø, et al, 2002).

Nursing developments in one country influenced and expanded to other countries. First of all, influences from Europe were obtained. The founder of modern nursing Florence Nightingale (1820-1910), who founded School of Nursing in London in 1861, had influence on the whole Europe, including Estonia. The same decade became the beginning of midwifery and nursing education in Estonia (Onoper, 2008, 281-282).

Before the beginning of the World War II the speciality of nursing had quite a high prestige in the whole Baltic region. Unfortunately the development of nursing science and education was slowed down by the Soviet occupation. The integration of nursing studies in the university programmes in Scandinavian countries took place already at the end of 1970s and at the beginning of 1980s, whilst we are making the first steps and efforts to reach the same level in Estonia nowadays. Nursing and nursing education have firmly anchored in Estonian educational system through the changes in society and its growth difficulties.

\section{Method}

Regarding the development of nursing profession, it is better understandable in every country if to take into account the history of the country, and the social and political factors, which have formed it, moreover it ables to accompany these changes. Research articles can be found in databases about the history of nursing and its development, about the origins of professional organisations and about the development of nursing education of almost every country. Unfortunately, there is no systematic overview about Estonia, yet. The present research is trying to fill this gap. Here is the main research problem: How has the development of the nursing profession and nurses' education changed in the course of Estonia's history and in the light of the factors affecting history?

This study is a retrospective article through which future visions can be projected. The research questions are: What kind of influence has Estonian nursing and nurses' education gained from external experiences within the development of society and from the restoration of Estonia's independence? How have teaching methods and curricula developed in modern Estonia? What are the prospects for the future considering the changes in the higher education landscape and historical experience?

Historical research method was used to analyse written nursing history in Estonia. Research materials included documentary sources found in archives, old newspapers, books, and journals pertaining to nursing education and practice. The amount of material was significant because the documented history of nursing education dates back to the early 19th century. The analysis of historical documents was conducted between 2015 and 2018. Historical research method used in the current research is a qualitative method, which involves studying, understanding and interpreting past events. The data were systematised, catalogued, mapped by periods and generalised. The exploratory nature of the study is opened through this article.

The data used in this research are also based on summarising and analysing relevant evidencebased studies, which have been conducted in several European countries. In addition to it, 


\section{International Conference on Research in Education}

documentary analysis was used to collect data (from 1991 to the present), to provide an insight into the development of modern curricula and teaching methods.

\section{Development of Estonian professional nursing in the context of changing society}

Nursing as a profession has existed throughout history, although it has evolved considerably over time. In the current health care system, nurses are one of the most trusted health care professionals with a significant role to perform in the treatment and medical care of the sick.

History of nursing stems from religion and military. These two separate fields are directly relevant to nursing and are responsible for its development as a full-fledged profession. Going back to early times, there were religious practices that encouraged nuns and religious figures to tend to the sick, as it was considered a noble thing to do. The need to help the sick was particularly felt in times of conflict, with wounded soldiers and epidemics outbreaks. During that time, the priests and the nuns took care of them. Gradually, the need for experts in the field was felt, and that is how the focus started shifting towards nursing as a proper line of work. Professionalism has played a vital role in the development of nursing as a speciality throughout the history. Based on that, there are four distinctive periods that can be identified in the development of nursing in Estonia.

\subsection{The early years of nursing}

The history of nursing in Estonia goes back to 1700s, when deaconesses took care of the weak and the sick. Orders of nuns and munks were devoted to taking care of the sick at that time. After the incorporation of Estonia into Russia (1710) the first marine hospital was opened in Tallinn in 1715 (Juske, 2016). The first nurses came to work from Russia to Estonia in 1724, following the order of Peter the Great, and started to work at the same hospital (Sooväli, 1998). The development of nursing was supported by opening of hospitals. At that time there was a huge shortage of midwives, nurses and feldschers. Although the first midwifery school was opened by Tartu University Midwifery Clinic already in 1811, professional nursing training was initiated only in the second half of 19th century, when the preparation of nurses-wounddressers-cupping practitioners started (Kuppo ja aadrelaskjad, 1863).

Nursing education attained a formal status in the 1860's, and that is where Florence Nightingale comes in. Students came from all over the world to attend Nightingale's school, and after completing their studies they returned to their home countries, mostly as managers and educators. Nursing education was, in its early phase, dominated by students working in the clinic to obtain their training, which was organised in accordance with an apprenticeship system (McMillan \& Dwyer, 1989; Tallberg, 1994; Sarkio, 2007).

However, this first period is largely characterised by the training of bedside nurses and nurses at the churches and monasteries. In 1867 the Tallinn House of Deaconesses was opened that served as a nursing home and a nursing school. The first Estonian sisters of mercy came from that school (Sooväli, 1998).

In 1872 the Estonian Ladies Committee of the Russian Society of Care about Wounded and Sick Soldiers was founded with the aim to make preparations for providing medical care in war conditions and to prepare sisters of mercy (Kõrran, et al, 2008, 13, 46). The first time when the attention was paid to the working conditions of nurses happened in 1880s. In 1893, preparation of 


\section{International Conference on Research in Education}

feldschers to work with doctors in St. Petersburg was started. A year later, in 1894, a private nursing school was opened by Mellin's clinic in Tartu. In 1912 the first Estonian girls were accepted onto the course. In 1925 Mellin's clinic gained the status of a state school. Pupils were called deaconesses and teaching was conducted in the German language (Onoper, 2008, 285-315). During the World War I the profession of a sister of mercy became very popular among young women. Women wanted to contribute equally with men and feel themselves needed during the war; and the number of applicants to become a sister of mercy drastically increased (Halastaja õde, 1914).

\subsection{Period of openness and professionalism}

During the period of the first Republic of Estonia (1918-1940) a lot of attention was paid to public health and application of anti-epidemic measures, with the emphasis on nurses' training. Ideas for the development of nursing and training of nurses mainly came from Germany and Scandinavia. Till the beginning of 1920 s the state health care system had gained general public approval. Alongside state education, a great role in nursing training was played by voluntary professional organisations like Red Cross (1919) and Estonian Association of Sisters of Mercy (1922). These associations created possibilities for the preparation of nurses and midwives. In 1920 the Estonian Red Cross Nursing School was opened by Tallinn Central Hospital. In 1925, at the request of the Estonian Nurses Union, a nursing school was opened by the Medical Faculty of Tartu University. Later on the school became Tartu Medical School (Oponer, 2008, 301-316).

During that period professional associations were acting very efficiently in Estonia, Latvia and Lithuania, organising conferences and establishing international contacts. The members of the Estonian Nurses Union took actively part in international conferences and congresses (Riga, Helsinki, Paris, Brussels), where questions of vocational education, public health, curricula of nursing schools and possibilities of their improvement were discussed (Oponer, 2008, 301-316). International cooperation that had begun at that time allowed to send nurses of Estonia abroad for refresher training courses, e.g. to London (Tähelepanemiseks..., 1921) and New York (Stipendium..., 1925).

In 1928 the Baltic Committee of Sisters of Mercy was established. The purpose of the Baltic nurses' organisation was to discuss professional issues and cooperate in raising the professional standards of nursing. The Baltic nurses agreed that nursing theory and practice should be supervised by nurse instructors and not by physicians. Professional training was supposed to last for two years, and only the ones with secondary school education were to be accepted onto the courses. It was admitted that there was a need for professional self-development in different fields of nursing, especially in public health (Oponer, 2008, 425).

Various social services were offered during the first Republic of Estonia, social welfare and health care were built on a sound basis. Only nursing school graduates were allowed to work as a nurse. (Kõrran, et al, 2008). Before the World War II nursing profession in all three Baltic countries Estonia, Latvia and Lithuania - was characterised by high prestige, powerful professional associations, wide international contacts, and strict control over nursing curricula and working conditions (Kalnins, et al, 2001). Nursing as a profession expanded between the World War I and II. The nurses were striving for the improvement of their training and working contitions by using oral discussions and professional organisations (Karosas \& Riklikienè, 2011).

\subsection{Period of suppression and hierarchy}




\section{International Conference on Research in Education}

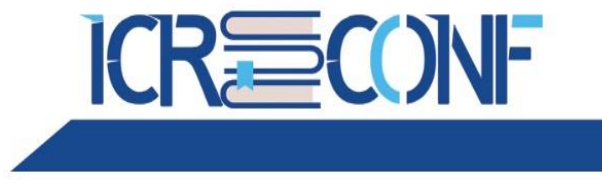

5-7 APRIL, 2019

BARCELONA, SPAIN

During the period of Soviet regime (1940-1991) the previously built nursing training system was demolished like many other education systems. After the involuntary incorporation of all three Baltic States into the Soviet Union, the nurses lost their professional status and were assimilated into the Soviet health care system as mid-level medical workers, who were trained in technical schools after the completion of primary school (Kalnins, et al, 2001). During the World War II all activities of medical schools in Tallinn and Tartu were interrupted, although the Tallinn Medical School continued in Tambov (Russia) till 1943.

After the end of the war tuition in medical schools was provided on the basis of general and secondary education. During the Soviet period the schools operated under different names that were changed according to political decisions. In the course of time shools have emerged and dissapeared. Nurses in Estonia were trained just like in other member states according to the centrally elaborated programmes.

After the World War II no significant changes took place in the health care policy of the Soviet Union. In towns health care was mainly provided by polyclinics and hospitals. In the countryside, basic medical treatment was administered by feldscher units and midwife units, more complex and specialised care was provided by larger district hospitals and district polyclinics (Tulva, 1995).

Suppression and hierarchy are inherent to this period. This period is characterised by turning off nurses' professional prestige, closing into a narrow circle, and domination of teaching of technical skills over the development of thinking. Profession of a nurse in the Soviet Union was characterised by absence of autonomy, bad working conditions and insufficient salary. Description of the main role of a nurse in publications was astounding. It was described "as an indisputable executor of doctors' orders and commands". The publications never mentioned an independent role of a nurse in the assessment of patient's condition and planning and application of nursing care (Kalnins, et al, 2001).

A nurse had to have knowledge about diseases and skills to complete different medical procedures. The quality of nurse's work was assessed on the basis of their speed and accuracy. A nurse had to be obedient and independence of nurses was suppressed. In 1980s the health care systems of the Baltic region were lagging far behind the Western standards. There was a shortage of employees, medicine and equipment. The ratio of hospital beds and patients was disproportional. The main shortage was of support staff, including nurses and paramedics (Healy \& McKee, 1997).

Till the end of 1970s - beginning of 1980s all resources were exhausted and economic misery reached the health care system. Primary health care was totally left for polyclinics with elderly personnel with low status, without the necessary training and ability, to offer only extremely lowquality service. Top-medicine was concentrated into hospitals. The collapse of the Soviet Union caused the collapse of the health care system of the time and everything had to start from scratch to be built up.

Centralisation of Soviet authorities had a deep impact on health care system, there were almost no international contacts and a significant state of closure occurred in all sectors, including health care.

\subsection{Period of critical change and the development of modern curricula}

The development of Estonian nursing education was interrupted for several decades by the World War II and Soviet occupation. In the immediate aftermath of the collapse of communism, each 


\section{International Conference on Research in Education}

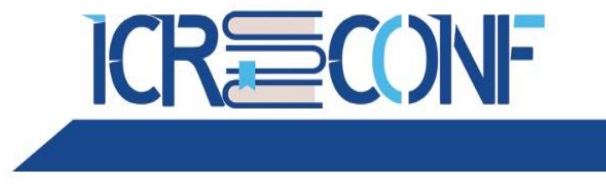

5-7 APRIL, 2019

BARCELONA, SPAIN

country faced a major economic shock with failing economic output and rising inflation (Healy \& McKee, 1997). The collapse of the Soviet Union in 1991 not only changed the political map of Europe but also brought about many other fundamental changes in the countries affected, including economic collapse and, in some places, war. Each country had to build a new national identity, with new constitutions, political systems, the symbols of nationhood and new ways of doing things, including the provision of health services (Rechel, et al, 2014, 1).

After Estonian restoration of independence, the health care education was also changed, following the examples of European educational systems (Ernits \& Sepp, 2010). The first major change took place in the beginning of 1990s, when nursing curricula based on general education ( 2 years and 10 months) were closed and programmes based on secondary education were opened (1 year and 10 months) (Ernits \& Sepp, 2010; Kannus \& Varik, 2011).

Already before the restoration of independence in 1991, national nursing unions were reestablished in all three Baltic States. They looked back into their history and past achievements with pride and investigated international experiences of different models of nursing practice and education. The importance of teamwork in the whole nursing process was emphasised for the first time (Kõrran, et al, 2008). The new era meant major challenges both for the system of social and health care, as well as for educational institutions. Social progress was quick and intensive. Activities of the Estonian Nurses Union (ENU) expanded significantly and international contacts, especially with Finland, Sweden and Denmark, were deepened. (Ende, 2000).

Like in Western European countries the development of nursing in Estonia was based on human rights, ethics and understanding of human approaches. A holistic approach (Rauhala, 1989) to a human became the theoretical basis of Estonian nursing and its organisation, aimed at well-being and recovery of a patient. Well-being of a patient is influenced by different factors like health and environment. Cultural sensitivity has also been considered important. These references were considered in development of nursing science. Nursing science plays a certain role in Europe, just like in the whole world. Centuries-old traditions of nursing science have developed its specific knowledge basis and academic education based on this knowledge (Tomey \& Alligood, 2010).

The development of the relationship between nursing science and the society has been little studied from the point of view of the nursing scientists, health care employees, sociologists, philosophers, nursing science students, doctors and the patients. Vuolanto (2015) focuses on transformation thesis and highlights that the relationships between nursing science and studies of society are transforming and changing in the course of time.

However, there are other views (Gibbons et al, 1994, 3-4; Etzkowitz \& Leydesdorff, 1998, 204), according to these, specialists of various fields participate in knowledge creation, and it can be talked about transdisciplinarity of knowledge creation. Influences, risks and problems of the society are to play an important role in the development of nursing. Nursing education in Estonia has started to acquire interdisciplinary nature, and it is not narrowly oriented anymore. Nursing problems would be solved in collaboration with several parties. At the same time, it is confined that professional academic context is the most important regarding the relationships between nursing science and society (Etzkowitz \& Leydesdorff, 1998, 204).

We have taken into account both, profession-centeredness and interdisciplinarity in the development of the curricula. One of the most important activities of higher education institutions 


\section{International Conference on Research in Education}

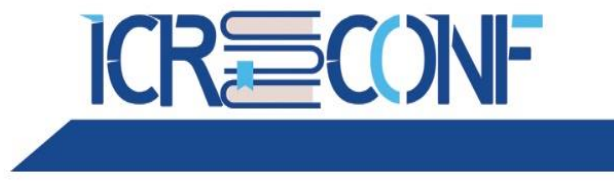

5-7 APRIL, 2019

BARCELONA, SPAIN

is the development of curriculum or course outlines in consonance with the national and international demands and realities. The key component of any curriculum is its learning outcomes.

In 1991 the department of nursing science was opened by Tartu University Faculty of Medicine. Studies in nursing science were opened in the academic year 1991/1992. Studies were conducted according to the 3-year curriculum and the first students graduated in 1994 (Aro, 2006). Nurses, midwives and other professional specialists were continuously trained in medical schools in Tallinn and in Tartu.

The teaching problems connected with the search for new approaches in professional training of nurses after the Soviet period are described by the nursing professor of Saint Louis University of US state of Missouri Irene Kalnins: „In 1991 the development of new curricula and selection of students was started in all three Baltic states. Economic and political considerations demanded as quick implementation of new study programmes as possible, but it was not possible without passing the research and planning phase. Lecturers from Estonia, Latvia and Lithuania got acquainted with BA curricula in Scandinavia and USA and tried to adapt them according to the needs and possibilities of all three coutries. That is why it is not suprising that all curricula had strong medical emphasis and only a limited part supported the role of nursing. Programmes in all three higher education institutions were led by doctors; and most of the lecturers were also doctors. Conceptual framework of nursing, philosophy and common core of competencies that must be acquired were missing in the curricula." (Kalnins, 1995).

The Estonian Nurses Union became the member of International Nurses Union again in Madrid in 1993. ENU promotes evidence-based nursing together with Tartu University, professional higher institutions and the Ministry of Social Affairs; participates in the preparation of health care regulations and identifying training needs; improvement of nursing terminology and harmonisation of nurses' standards of competency. The union also coordinates international relations of the field (Kõrran, et al, 2008).

Together with Danish lecturers, preparation of the European curricula for nurses in medical schools was started. In the academic year 1996/97 medical schools started providing education at the level of professional higher education. Although the beginning was quite chaotic and complicated, the cooperation of Danish Nurses Union, ENU and Tartu University ended with the preparation of a joint curriculum for nursing specialities ( 3 years and 6 months) of all schools providing nursing education. Lecturers were offered a special additional training course, mainly led by Danish nursing lecturers (Ernits \& Sepp, 2010, Kannus \& Varik, 2011; Sõerde, 2013.)

Bachelor (BA) curriculum was launched by the University of Tartu in 1997/1998 and Master's curriculum in 1998/1999 (Aro, 2006). The goal was to prepare nurses with high level academic education - specialists with analytical skills and critical thinking - who were able to affect nursing education and development. The need for nurses with academic higher education arose with the development of health care system. Nurses with academic education were needed to fill the positions of a head nurse, nursing managers and other managerial positions, as well as for teaching nursing students (Ende, 2000).

Changes in the Estonian society have created several possibilities for the elaboration of new health care policy. Earlier achievements have been analysed and history of health care has been studied 


\section{International Conference on Research in Education}

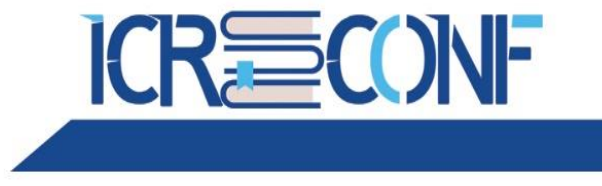

5-7 APRIL, 2019

BARCELONA, SPAIN

again and again, with the aim to transfer the results of analyses to current practice. In 1996 a magazine Eesti Õde (Estonian Nurse) was founded. Eesti Õde is published four times a year and publishes information about the research in the field of nursing. The necessary evidence-based medical information can also be acquired from scientific articles published in the magazine Eesti Arst (Estonian Doctor).

The professional standard of a general nurse, approved by the Health and Social Care Qualification Authority, was adopted in June 1999. The professional standard of a nurse includes a list of knowledge and skills about social work, knowledge of law, etc. A nurse in Estonia today is independent and competent; works with families and cooperates with other spheres; knows legislation and is a contact person between different authorities. Due to the new occupational requirements it is necessary to stress the aspects connected with social nursing in nurses' work. In addition to legal acts (Tervishoiuteenuste.., 2001), nurses' work is regulated by the International Code of Ethics of the Nurses' Union (The ICN..., 2012), the aim of which is to support nurses in everyday decision making.

Pursuant to Bologna Process, nursing education is regulated with laws of higher education in every country (Råholm, et al, 2010). Nurses' training has been harmonised and Estonian nurses can work all over the Europe. According to the Bologna declaration and 3+2 system a new Master's curriculum was launched in Tartu University (2002). The new curriculum (120 ECTS) is more concentrated on the specialisation of nursing management and pedagogy. Curricula development, including the application of international specialists and preparation of lecturers, was supported by the Republic of Estonia and the European Union (Aro, 2006). Graduates of Master's curriculum are working as lecturers in professional higher education institutions, as nursing managers, and as ward nurses in hospitals. Some of the graduates are working in public office, such as the Ministry of Social Affairs or the Ministry of Education and Research.

The need for nurses with doctoral degree has been pointed out in the Estonian Nursing Development Strategy for the years 2011-2020 "Eight steps for human wellness" (Kaheksa..., 2011) that aims at increasing the number of nurses with doctoral degree to support the development of nursing science as an important academic discipline and sustainability in Estonia. Today there are four Doctors of Health Sciences in Estonia with the specialisation on Nursing Science (Hinno, 2012; Toode, 2015; Demidenko, 2018; Ernits 2018), who have studied in Finland and are working as nurse managers and educators. In addition, some practising nurses are also $\mathrm{PhD}$ students of some other curricula in Estonia. Therefore we can state that the future of nursing in Estonia is hopeful.

Nowadays, nurses are trained at the level of professional higher education in Tallinn, Kohtla-Järve, Pärnu and Tartu; since 2019 also in Kuressaare. Health care colleges offer nursing training at three levels: basic nursing education, professional nursing training and advanced professional training (Pruuden, 2011). Current basic nursing curricula correspond to the Standard of Higher Education (Kõrgharidusstandard, 2008) and the directives of the European Union. Curricula (210 ECTS) integrate theory with practice. A person who has successfully passed basic nursing curriculum can work as a nurse in all spheres in health care in Estonia or other European countries.

During last decades, the expectations of people and society to the higher education have significantly changed. Legislative framework must follow the students' needs that have changed, and also with processes of change in the society. The higher education reform derives from new law of higher education, which was developed with the aim to organise and simplify the regulation 


\section{International Conference on Research in Education}

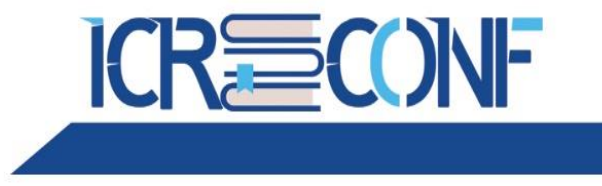

5-7 APRIL, 2019

BARCELONA, SPAIN

from the 1990s and to highlight several substantive amendments. As an example, the graduate of professional higher education obtains Bachelor's degree from now on. Pursuant to the law in renewal the organisation of Master's studies shall be more flexible (Kõrgharidusseadus, 2018). There is an increasing need of MA specialists in health care. At this point, there is a good example of the Curricula of Master's Studies in Health Sciences established by Tallinn Health Care College and Tartu Health Care College with duration of 1.5 years (90 ECTS), which was opened in 2018, and there are currently approximately 120 students studying in both higher education institutions (at specialisations of health nursing, mental health nursing, clinical nursing and intensive nursing).

\section{Modern learning methods and international cooperation}

In addition to traditional methods the innovative methods are also used in instructing the speciality of nursing. Curricula have been developed in cooperation of both health care colleges, and are following the same principles and trends. Tallinn Health Care College is developing simulation learning and application of NANDA- ${ }^{1}$ nursing diagnoses and research.

In 2000 it was found out that there was a need to teach nursing process and how to document it. A unified language had to be found, based on terminology of nursing activities (Puusepp, 2017). That is why NANDA was introduced (since 2002 NANDA International, shortened NANDA-I), which is an evidence-based classification established in the US in 1982. NANDA-I diagnoses are research objects also in the future, and if necessary, changes and supplements will be added once in every three years (Herdman 2013; Herdman \& Kamitsuru, 2016). Estonia is one of these 16 countries in the world NANDA-I diagnoses are available in the national language. By 2017 almost one third of all the nurses in Estonia had passed NANDA-I main exam either after completing main courses or continuing training courses (Puusepp, 2017).

Another new teaching method is the simulation. As science, technology and education evolve, simulation has become an innovative teaching strategy for nursing skills (Fisher \& King, 2013). Simulation is considered as an inseparable part in acquiring nursing education (RutherfordHemming, et al, 2016). Modern simulation means high-tech equipment, which allows to create a situation, which seems significantly real. High-tech simulator-doll is able to simulate physiological reactions, symptoms of conditions and the course of these symptoms and to record all the nursing care interventions. (Nehring \& Lashley, 2009).

Currently, the basis for planning and conducting learning in simulation at Tallinn Health Care College are the standards of good practice of simulation developed by INACSL (The International Nursing Association for Clinical Simulation and Learning). (Ristikivi, 2016).

Modern learning methods have also contributed to the intensification of international relations. International cooperation of health care colleges is based on the international trends of Estonian higher education institutions and development needs of colleges and curricula. An important part of international cooperation is mobility of learners and teachers (Erasmus+ mobility programmes), development projects (NordPlus programme) and participation in international networks and workgroups.

\footnotetext{
${ }^{1}$ NANDA International (formerly the North American Nursing Diagnosis Association) is a professional organization of nurses that develops, researches, disseminates and refines the nomenclature, criteria, and taxonomy of nursing diagnoses.
} 


\section{International Conference on Research in Education}

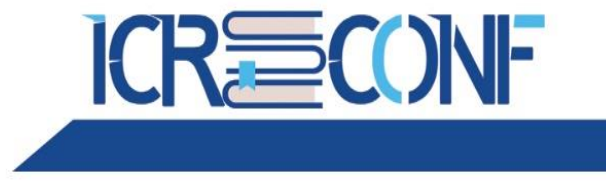

5-7 APRIL, 2019

BARCELONA, SPAIN

International networks the college is participating in can be divided into higher education networks like EURASHE (European Association of Institutions in Higher Education), IUHPE (European Association of Institutions in Higher Education) ja COHEHRE (Consortium of Institutes of Higher Education in Health and Rehabilitation in Europe) and professional networks like, for example, ATCN (Advanced Trauma Care for Nurses), ENOTHE (European Network of Occupational Therapy in Higher Education), and EAOO (European Academy of Optometry and Optics).

The health care colleges are participating in research projects, developing nursing education and practice and organising international and local conferences and seminars. Research and development are conducted in cooperation with social and health care organisations, training organisations and the third sector (Ernits \& Sepp, 2010; Kannus \& Varik, 2011).

\section{Need for health care workers and migration of nurses}

Migration of nurses has been a problem in Estonia in recent years. Worldwide, there is a dramatic shortage of nurses. An increase in the migration of nurses from their home countries to recipient countries is having a global effect on the health care system. Migration has a significant impact at both the individual and national level. The main reason for moving abroad from Estonia was connected with remuneration. Possibilities for additional training and professional practice were also considered important, as well as disappointment in the Estonian life and/or the specific health care institution (Adamson, 2014, 7). European Union legislation in force supports the mobility and migration of health care workers, that in the context of Estonia means one-way movement from Estonia. Heavy ship traffic between Tallinn and Helsinki enables to work simultaneously in Estonia and in Finland. The largest number of nurses leave for Finland, Sweden, Denmark, Norway, Great Britain and other countries where there are not enough nurses (Kiivet, et al, 2013).

Nursing can increasingly be characterised like a mobile profession, one can manage with it all over the world. Health care employees and their knowledge is universal, as it can be applied in the same way in every country, which makes migration between countries easier (Võrk, et al, 2004, 8-10). Thousands of nurses migrate every year in a search for better salary and work environment, possibilities for career, professional development, personal security or novelty and adventures (Kingma 2007; Freeman, et al, 2012). The increase of the professionally educated nurses' international migration from Estonia to work in higher income countries was particularly striking in the years 2006-2016. Now the problem shows a declining trend.

\section{Discussion and conclusions}

Estonian nursing and nursing education have not been developing as a lonely islet in the middle of an ocean but it has acquired a lot of influence from all over Europe. The historical and sociocultural context has acutely emerged in the context of the wind of changes in society. The four emerging periods of educating nurses in Estonia have changed the development and prestige of the profession, and this knowledge contributes to the present and future of nurses' profession.

Although the Estonian nursing and nursing education developed in parallel with Europe and reached quite a high level before the beginning of the World War II, the further development was restrained by the prolonged war and the following Soviet occupation. Nurses lost their professional standing and autonomy. Nursing profession in the Soviet Union was characterised by low prestige, lack of autonomy, poor working conditions and insufficient salary. It has been very hard to 


\section{International Conference on Research in Education}

overcome such image after the Estonian reindependence. We may say that we have not really succeeded to do that till now. Doctoral studies and academic nursing that were started in Scandinavian countries already in 1980s, only start to develop in Estonia in recent years.

Nursing care has to be based on scientific knowledge and results of research work that is a challenge for the lecturers. It is especially important here to apply to practice scientific work results and their inclusion into the study programme. The quality of nursing education can be raised by systematic training of the supervisors of practical training and modernisation of training programmes in cooperation with traineeship institutions. Curricula are improved according to the requirements of labour market and the needs of the patients of the European Union and Estonia.

Both the development of health technologies and aging population increase the need for nursing care (Tulevikuvaade..., 2017). Nurses have the key role in the functioning of modern medical care and their role is enormous in helping countries deal with the continually growing number of chronic patients. A nurse today is a specialist, who can see, assess and analyse patient's needs, set goals for personal activities and draw up a nursing plan for nursing operations. It is important to have nurses working together with other specialists in the field (social workers, therapists, psychologists, etc.), productivity of nurses depends largely on organisational culture and working environment (Ernits, 2018).

The purpose of the Bologna process has been to create harmonised, comparable and high-quality curricula. But it has brought another problem, too - an increasing number in the migration of nurses from Estonia to the neighboring countries. Nurses leaving abroad increase the need for their training. But we have to ask a serious question - why do we train and educate our nurses for other countries instead of increasing their salaries and developing the working conditions? Over the last three years, hospitals have been constantly improving the working conditions of nurses and introducing new technologies and digital solutions to make nurses' work easier. This has helped to increase the quality of nurses' work. As a result, migration has now been stopped.

Analysing and discussing the results of the research allows us to point out the following:

- Knowing the history of the profession and gradually solving the problems arising from our developmental story, geographical location and societal specificity, we can hopefully look forward to the future, set the goals in order to meet the demands of society.

- The need for nurses' training is growing because we have a lack of nurses. This is a serious challenge for the health care colleges. There is a need for continuous improvement of curricula and, if necessary, opening new ones to meet the requirements of a rapidly changing society. Prerequisite for the provision of effective and high-quality nursing are nursing research papers of lecturers and students and their application into practice. This helps to improve scientificbased approach in nursing education.

- The main challenges for the coming years are: to continue the improvement of the working conditions of nurses and develop new technologies to motivate trained nurses to work in Estonia; strengthen international cooperation and participation in networks in order to be in close contact with specialists from the neighbouring countries. The opportunities and effective use of digital culture are a good basis for internationalisation.

The past is in the future and the main educational challenges arise from our history and background. The quality of nursing education can be raised by systematic training and modernisation of training programmes and learning methods as well as by strengthening research 


\section{International Conference on Research in Education}

work. Curricula must be constantly updated and improved according to the requirements of labour market and the needs of the patients of the European Union and Estonia. As seen from the results of the study, Estonian nursing has achieved its place in the Estonian educational landscape as a profession, a teaching discipline and a field of research.

\section{References}

1. Adamson, K.: Eesti ódede kogemused migreerumisest (Experiences of migration of Estonian nurses), Master thesis, University of Tartu, Faculty of Medicine, Department of Nursing Science, 2014

2. Aro, I.: Õendusteaduse osakond 1991-2006: 15 aastat akadeemilist õendusharidust Eestis (Department of Nursing Science 1991-2006: 15 years of academic nursing education in Estonia), Tartu Ülikooli arstiteaduskonna õendusteaduse osakonna juubelikonverentsi kogumik, 10.10.2006, Tartu, 2006

3. Demidenko, J.: Older patients' and their families' wellness and social support in emergency departments, Doctoral dissertation, University of Tampere, Department of Health Sciences, 2018

4. Dunbar, V.: Nursing in Northern Europe, American Journal of Nursing, 37, 123-130, 1937

5. Ende, E.: Leedid lambikesega (Ladies with Lamp), Terviseleht, 16, 2000

6. Ernits, Ü. \& Sepp, A.: Tallinna Tervishoiu Kõrgkool 1940-2010: artiklite kogumik (Tallinn Health Care College 1940-2010: Collection of articles), Tallinn: Tallinna Tervishoiu Körgkool, 2010

7. Ernits, Ü.: Viron hoitotyön kehittyminen ja muotoutuminen yhteiskunnallisessa muutoksessa: seurantatutkimus (Development and formation of Estonian nursing in the changes of society: Retrospective study), Doctoral dissertation, Acta Universitatis Tamperensis 2372, Tampere University Press, 2018

8. Etzkowitz, H., Leydesdorff, L.: The triple helix as a model for innovation studies. Science and Public Policy, Volume 25, Issue 3, 195-203, 1998

9. Fisher, D. \& King, L.: An integrative literature review on preparing nursing students trough simulation to recognize and respond to the deteriorating patient, Journal on Advanced Nursing, 69(11), 2375-88, 2013

10. Freeman, M., Baumann, A., Blythe, J., Fisher, A. \& Akhtar-Danesh, N.: Migration: A concept analysis from a nursing prespective, Journal of Advanced Nursing, 15(5), 1175-1186, 2012

11. Gibbons, M., Limoges, C., Nowotny, H., Schwartzman, S., Scott, P., Trow, M.: The new production of knowledge: The dynamics of science and research in contemporary societies. London: SAGE, 1994

12. Halastaja õde: ettekujutus halastajaõest: iseloom, välimus, tööst sõja ajal (Sister of mercy: The idea of a sister of mercy: character, appearance, work during war), Tallinna Teataja, 30.09., 222, 1, 1914

13. Healy, J. \& McKee, M.: Health sector reform in central and eastern Europe: The professional dimension, Health Policy and Planning, 12(4), 286-295, 1997

14. Herdman, H.T., Kamitsuru, S.: Õendusdiagnoosid. Definitsioonid ja klassifikatsioon 2015-2017 (Nursing diagnoses. Definitions and classification 2015-2017), Greif OÜ, 2016

15. Herdman, H.T.: Õendusdiagnoosid. Definitsioonid ja klassifikatsioon 2012-2014 (Nursing diagnoses. Definitions and classification 2012-2014), Tartu: Elmatar, 2013

16. Hinno, S.: The professional practice environment: Hospital nurses' perspectives in three European countries, Publications on the University of Eastern Finland, Dissertation in Health Sciences, Kuopio: University of Eastern Finland, Department of Nursing Science, 2012

17. https://www.koda.ee/sites/default/files/content-type/content/201805/Eeln\%C3\%B5u_K\%C3\%B5rgharidusseadus.pdf (04.03.2019)

18. Juske, J.: Härjapea jõe saladus (The secret of the Härjapea River), Tallinn: Hea Lugu, 2016

19. Kaheksa sammu inimese tervise heaks. Eesti õenduse ja ämmaemanduse arengustrateegia 2011-2020 (Eight steps for human health. Estonian nursing and midwifery development strategy 2011-2020), Tallinn: Eesti Õdede Liit, Eesti Ämmaemandate Ühing, 2011. Retrieved from https://tervis.ut.ee/sites/default/files/tervis/eesti_oenduse_ammaemanduse_arengustrateegia.pdf (20.02.2019)

20. Kalnins, I.: Pioneers in academia: higher education for nurses in Estonia, Latvia and Lithuania, Nursing Outlook, 43, 84-87, 1995 


\section{International Conference on Research in Education}

21. Kalnins, I., Barkauskas, Violet, H. \& Sesskevicius, A.: Baccalaureate nursing education development in 2 Baltic countries: Outcomes 10 years after initiation, Nursing Outlook, 49(3), 142-147, 2001

22. Kannus, A. \& Varik M.: Tartu Tervishoiu Kõrgkool - de facto 200 ja de jure 6 aastat tegevuse algusest, (Tartu Health Care College - de facto 200 and de jure 6 years since start of activity), Eesti Arst, 90(11), 538-539, 2011

23. Karosas, L. \& Riklikienè, O.: Development of the nursing profession in pre-war independent Lithuania (1918-1939): A comparison between past and present, The Journal Nursing Education, Research, \& Practice, 1, 4-11, 2011

24. Kiivet, R.-A., Visk, H. \& Raag, M.: Õdede arvu prognoos aastaks 2032 (Estimated number of nurses by 2032), Eesti Arst, 92(11), 616-626, 2013

25. Kingma, M.: Nurses on the move: A global overview, Healt Services Research, 42(3), 1281-1298, 2007

26. Kõrgharidusseadus: eelnõu (Higher Education Act: Draft), 07.05.2018. Retrieved from

27. Kõrgharidusstandard (Higher education standard). Accepted 18.12.2008, No 178. RT I 2008, 57, 322. Retrieved from https://www.riigiteataja.ee/akt/13255227?leiaKehtiv (04.03.2019)

28. Kõrran, T., Onoper, A., Pruuden, E., Roots, E., Ruul-Kasemaa, K., Saluvere, T., Sarv, H. \& Õunapuu, M.: Sammud käänulisel teel: Eesti õenduse arengutest 21. sajandini (Steps in a twisted road: developments in Estonian nursing to the 21st century), Tartu: Eesti Õdede Liit, 2008

29. Kuppo ja aadrelaskjad (Putting the cups and letting blood), Perno Postimees, 9.01., 2, 12, 1863

30. Kyrkjebø, J. M., Mekki, T. E. \& Hanestad, B. R.: Short report: Nursing education in Norway, Journal of Advanced Nursing, 38(3), 296-302, 2002

31. McMillan, M. \& Dwyer, J.: Changing times, changing paradigms (1): From hospital training and college education in Australia, Nurse Education Today, 9, 13-18, 1989

32. Nehring, W., Lashley, F. R.: Nursing simulation: A review of the past 40 years, Simulation Gaming, 40, 528-552, 2009

33. Onoper, A.-M. (comp.): Ülevaade õdede, ämmaemandate ja velskrite ajaloost ja tegevusest: Bibliograafia. (An overview of the history and activities of nurses, midwives and feldshers: Bibliography), Tartu: Eesti Õdede Liit, 2008. Retrieved from http://www.kirmus.ee/resources/pdf/bibl_final.pdf (01.03.2019)

34. Pruuden, E.: Eesti õenduskoolituse strateegiline juhtimine - NÕKK (Strategic Management of Estonian Nurses' Training), Eesti Õde, 3, 9-10, 2011

35. Puusepp, K.: Kümme aastat NANDA-I jälgedes (Ten years in the footsteps of NANDA-I), Eesti Õde, 1, 28-30, 2017

36. Råholm, M.-B., Hedegaard, B. L., Löfmark, A. \& Slettebø, A.: Nursing education in Denmark, Finland, Norway and Sweden - from Bachelor's Degree to PhD, Journal of Advanced Nursing, 66(9), 2126-2137, 2010

37. Rauhala, L.: Ihmisen ykseys ja moninaisuus (Human Unity and Diversity), Helsinki: Sairaanhoitajien koulutussäätiö, 1989

38. Rechel, B., Richardson, E. \& McKee, M.: Introduction. In: Trends in health systems in the former Soviet countries (pp. 1-7). Edited by Bernd Rechel, Erica Richardson, Martin McKee. Observatory Studies Series 35, Copenhagen, Denmark: WHO Regional Office for Europe, 2014

39. Ristikivi, J.: Simulatsioonil kasutatavad õppemeetodid ja nende rakendamise tulemuslikkus õdede õppes: integreeriv kirjanduse ülevaade (Learning methods used in simulation and the effectiveness of their implementation in nursing learning: An integrative review of literature), Master thesis, University of Tartu, Faculty of Medicine, Department of Nursing Science, 2016

40. Rutherford-Hemming, T., Nye, C. \& Coram, C.: Using simulation for clinical practice hours in nurse practitioner education in the United States: A systematic review, Nurse Education Today, 37, 128-135, 2016

41. Sarkio, M.: Sairaanhoitajaksi Kasvattaminen. Sairaahoitajakoulutus ja Siina kaytetyt oppikirjat suomessa vuoteen 1967 asti (The historical development of Finnish nursing textbooks from the late 1880s to 1967 the training of nurses in the Foucauldian perspective), Doctoral dissertation, Research Report 208, Department of Education, Helsinki: University of Helsinki, 2007

42. Sõerde K.: Ülevaade Tallinna Tervishoiu Kõrgkooli ajaloost (An overview of the history of Tallinn Health Care College), Eesti Arst, 92(3), 163, 2013 


\section{International Conference on Research in Education}

43. Sooväli, E.-M.: Õenduse ajalooline ülevaade maailmas ja Eestis (The historical overview of nursing in the world and in Estonia), Eesti Õde, 1, 18-19, 1998

44. Stipendium Eesti õdede ühingule (Scholarship for Estonian Nurses Union), Vaba Maa, 28.07., 171, 4, 1925

45. Tähelepanemiseks halastajatele õdedele (For attention to sisters of mercy), Tallinna Teataja, 16.09, 214, 1,1921

46. Tallberg, M.: Nursing and Medical care in Finland from the Eighteenth to the late Nineteenth Century. The Background for the Introduction of Nurses' Training in Finland in 1889 with some Comparisons with developments in Sweden, Nursing History Review 2, 169-190, 1994

47. Tervishoiuteenuse osutamise dokumenteerimise ning nende dokumentide säilitamise tingimused ja kord (Conditions and procedure for documenting provision of health care services and preservation of these documents). Accepted 18.09.2008, No 56. RTL 2008, 80, 1115. Retrieved from https://www.riigiteataja.ee/akt/107072011010?leiaKehtiv_(04.03.2019)

48. The ICN Code of Ethics for Nurses, Geneva: International Council of Nurses, 2012. Retrieved 27.02.2019. https://www.icn.ch/sites/default/files/inline-

files/2012_ICN_Codeofethicsfornurses_\%20eng.pdf

49. Tomey, A. M., Alligood, M. R.: Nursing Theorists and Their Work, 7th Edition. USA: Mosby Elsevier, 2010

50. Toode, K.: Nurses' Work Motivation. Essence and associations. Doctoral dissertation, Tampere: University of Tampere, 2015. Retrieved from http://www.rahvatervis.ut.ee/bitstream/1/6124/1/Toode2015.pdf

51. Tulevikuvaade töojõ - ja oskuste vajadusele: tervishoid (A vision for the need for labor and skills: healthcare), Tallinn: Kutsekoda, 2017. Retrieved from http://oska.kutsekoda.ee/wpcontent/uploads/2016/04/tervishoiu_uuringu_terviktekst.pdf (27.02.2019)

52. Tulva, T.: Viron sosiaalityön muotoutuminen murroskaudella (Formation of Estonian social work during the transition period), Akateeminen väitöskirja Rovaniemi: Lapin Yliopisto, 1995

53. Võrk, A., Priinits, M. \& Kallaste, E.: Tervishoiutöötajate väljaranne Eestist: väljarände suurus, mõju tervishoiutöötajate vajadusele ja voimalikud poliitikavalikud (Outreach of healthcare workers from Estonia: Size of emigration, impact on needs of healthcare professionals and possible policy options), Tallinn: Poliitikauuringute Keskus PRAXIS, 2004

54. Vuolanto, P.: The universities' transformation thesis revisted: A case study of the relationship between nursing science and society, Science and Technology Studies, 30(2), 34-52, 2015 